\title{
Saphenous vein harvest wound complications: risk factors, identification, prevention, and management
}

\author{
Mohammad Salman Siddiqi \\ Cardiothoracic Surgery Division, \\ Department of Surgery, Sultan \\ Qaboos University Hospital, \\ Muscat, Oman
}

This article was published in the following Dove Press journal:

Chronic Wound Care Management and Research

14 November 2016

Number of times this article has been viewed

\begin{abstract}
Coronary artery bypass grafting is a commonly performed surgery worldwide that gives good results. Great saphenous vein is used as a conduit for bypass in over $95 \%$ cases. The harvesting technique has remained unchanged over the years. However, wound complications from harvesting the great saphenous vein by open method can be a major source of postoperative morbidity. With the objective of preventing major complications, identification of risk factors for saphenous vein harvest site infection is important. It is imperative to develop approaches that prevent infection and to allow for early recognition of patients who are at high risk and who may need more watchful monitoring so as to prevent development of wound complications. It is desirable to assess the patient completely, delineate the anatomy of peripheral vessels particularly in a patient with associated peripheral vascular disease, identify the best site to perform the saphenous vein harvest incision, employ a meticulous surgical technique, recognize complications early, and start the recommended treatment without delay. The aim of this paper is to identify the risk factors for saphenous vein harvest site complications and their identification, prevention, and management.
\end{abstract}

Keywords: saphenous vein harvest, wound complication, coronary artery bypass grafting, risk factors, surgical site infection, endo vein harvesting

\section{Introduction}

Coronary artery bypass grafting $(\mathrm{CABG})$ is the most widely used treatment modality for patients with ischemic heart disease worldwide. ${ }^{1,2}$ Despite the increased emphasis given to the use of arterial grafts, the long saphenous continues to be the most commonly used conduit for $\mathrm{CABG}$ and remains the mainstay. In fact, majority of the patients complain of leg wound rather than sternal wound. The incidence of saphenous vein harvest site infection is reported to be between $1 \%$ and $24 \%$ in the literature. ${ }^{3-6}$ Very little has been discussed about the morbidities associated with great saphenous vein harvest site infection (GSVHSI) following CABG. These complications very rarely require major surgical intervention, and are disturbing, both to the patient and to the treating surgeon. Sometimes, major wound complications related to great saphenous vein (GSV) harvest site may prolong the patient hospital stay and may rarely require extensive debridement along with revascularization to salvage the limb, plastic surgical procedures, and sometimes, even amputation. These complications lead to delay in recovery and return to day-to-day activity, along with psychological trauma.

Risk factors associated with GSVHSI are multifactorial and include obesity, diabetes mellitus (DM), female sex, peripheral vascular disease (PVD), smoking, preoperative anemia, chronic renal failure, intra-aortic balloon pulsation (IABP) use, 
and operative technique. Cutaneous manifestation appears to be minor but may result in significant morbidity; it includes cellulitis, nonhealing ulcers, peripheral sensory deficit, and vein graft dermatitis.

The aim of this article is to identify the risk factors for complications of saphenous vein (SV) harvest site and its identification, prevention, and management.

\section{Risk factors associated with GSVHSI}

CABG is one of the most commonly performed surgeries in the world. There is an increase in the use of arterial grafts, but GSV is more commonly used as a conduit still. Traditional technique for harvesting the SV involves long continuous open skin incision, involving the entire leg most of the time. Much attention has been paid to deep chest wound infection and mediastintis because of the potential life-threatening effect. But in reality, SV harvest site infection is more common, which increases the morbidity, causes delayed discharge from the hospital, and increases the hospital costs. ${ }^{7-9}$

The causes of GSVHSI are multifactorial. Prevention is better than cure. Patients at increased risk of developing SV infection should be identified preoperatively and necessary precautions should be taken.

Risk factors associated with SV infection can be divided into preoperative (host) factors and peroperative (perioperative and postoperative) factors. Preoperative factors associated with increased incidence of SV infection include increased age, ${ }^{10,11}$ female sex,,${ }^{9,12-14}$ increased body mass index, ${ }^{9,10,13,14-16}$ and comorbidities such as DM, $, 911-13,17$ PVD,${ }^{11-13}$ low preoperative hemoglobin levels, ${ }^{14}$ congestive heart failure, and chronic renal failure, whereas the peroperative factors include duration of surgery, open technique of harvesting, ${ }^{1,18-21}$ harvesting from the leg with deep vein thrombosis, inappropriate use of electrocautery, and IABP use, and these factors are modifiable.

The major risk factors associated with SV infection are listed in Table 1.

The factors associated with increase of GSVHSI infection are elaborated below.

\section{Female sex}

It has been observed that leg wound complications are more likely to occur in female sex. ${ }^{12,22}$ The reason why females are more prone to SV infection is not clear. It has been suggested that females have smaller peripheral arteries than males, which may impair wound healing. Another hypothesis is that majority of women going for CABG are postmenopausal,
Table I Risk factors for developing saphenous vein harvest site wound complication following coronary artery bypass grafting

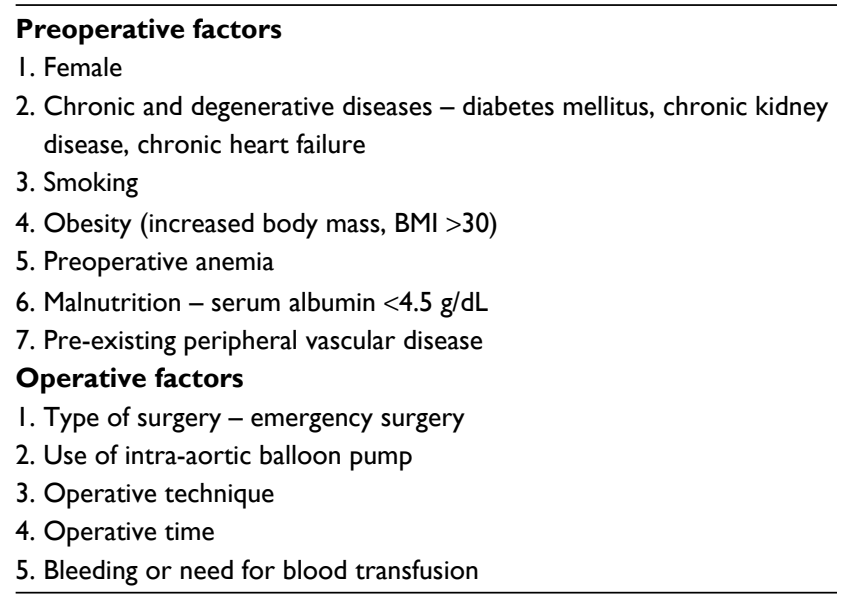

Abbreviation: BMI, body mass index.

and decreased estrogen levels in postmenopausal females may impair wound healing in addition to increasing the risk of coronary artery disease (CAD) after menopause. Estrogen receptors have been tagged in various skin cells, ${ }^{23}$ and administration of estrogen has been found to promote the release of platelet-derived growth factor alpha and to augment fibroblastic and myofibroblastic wound contraction. ${ }^{24}$

\section{Diabetes mellitus}

Significant correlation is found between DM and development of wound infection. DM is one the major risk factors for poor wound healing. In patients with poor glycemic control, hyperglycemia leads to higher concentration of glycosylated hemoglobin which has increased affinity for oxygen. This leads to low oxygen delivery at the capillary level, ${ }^{25,26}$ causing poor wound healing at the harvest site. Garland et $\mathrm{al}^{27}$ and $\mathrm{Ku}$ et $\mathrm{al}^{28}$ reported DM as the major risk factor for GSVHSI.

\section{Increased body mass index}

Obese patients are more prone to wound infection. ${ }^{3,13}$ These patients are more likely to develop hematoma, lymphocele, and poor wound healing.

\section{Peripheral vascular disease}

The presence of PVD greatly increases the risk of developing SV infection. ${ }^{10,12,29}$ Patients with CAD have increased incidence of PVD because of associated generalized atherosclerosis and diabetes. The peripheral arteries are narrowed and, in some cases, totally obstructed, and they rely on collateral circulation to supply blood to distal areas. If these collaterals are damaged during harvesting, it can jeopardize the circulation and impair wound healing. 


\section{Smoking}

Its association with poor wound healing is due to its association with PVD. Smoking decreases local skin blood flow, making the operative site more ischemic. Smokers have decreased keratinocyte migration due to blockage of cell receptor sites by nicotine. ${ }^{30}$ This leads to poor wound healing.

\section{Low preoperative hemoglobin}

Utley et al reported increased incidence of SV infection in patients with hematocrit $<35 \% .{ }^{13}$ This may be due to low oxygen delivery to the surgical site leading to poor wound healing.

\section{Deep vein thrombosis}

Deep vein thrombosis leads to varicose veins, which not only impairs the quality of vein but also if the vein is harvested from the same leg, leads to obstruction to venous return, thereby causing swelling of leg and, in extreme cases, can lead to venous gangrene, which is very difficult to treat and can result in amputation of the limb. Phlegmasia cerulea dolens is a rare form of acute deep vein thrombosis. It leads to sudden and severe venous hypertension which results in compartment syndrome. ${ }^{31,32}$ This leads to a reduction in the arteriovenous pressure gradient with subsequent reduction in microvascular perfusion. Consequently, there is nerve compression, tissue ischemia, and even venous gangrene can occur.

\section{Use of IABP}

The incidence of limb ischemia due to IABP use has been reported to be between $20 \%$ and $30 \%{ }^{33}$ This may be due to arterial obstruction or thrombosis due to IAB catheter. Sometimes, distal embolization can lead to limb ischemia. Other risk factors for developing limb ischemia from IABP include female sex (smaller arteries), DM, and smoking (associated PVD). ${ }^{34}$

\section{Dyslipidemia}

It increases the risk of impaired wound healing because of its association with PVD.

\section{Lymphedema}

Lymphedema is an abnormal accumulation of interstitial protein-rich fluid. The superficial inguinal lymph nodes and large lymph vessels accompany the GSV anatomically and are prone to damage during harvesting of GSV. The commonly reported lymphatic complications following SV harvesting are lymphatic fistula and lymphocele, which, in turn, can lead to impaired wound healing.

\section{Operative techniques}

The type of operative technique used in harvesting the conduit plays an important role in how the wound heals (Table 3). Different techniques of harvesting and the methods used for closure have implications on wound healing. Traditional method of harvesting using long continuous open skin incision compared to using bridge incision or minimally invasive endovein harvesting techniques are associated with increased problem of wound healing.

Good surgical technique is the ultimate factor in wound outcome, but the technique of closure also seems to affect the end result. Allen et al showed lower complication rate with endoscopic vein harvest technique compared to the traditional open method of harvesting. ${ }^{35}$ Angelini et al examined three methods of skin closure in their study: continuous vertical mattress, continuous subcuticular closure, and use of clips. They found significantly less wound discharge, inflammation, and infection with the subcuticular closure technique. ${ }^{36}$

\section{Identification and prevention}

Routine guidelines should be followed for preventing SV harvest site infection. These include meticulous skin preparation, preoperative antibiotic prophylaxis, use of proper surgical techniques, and wound management. Identifying the risk factors and acting in a timely fashion will prevent the modifiable causes of GSVHSI.

$\mathrm{DM}$ is a major risk factor for infection. Many centers are advocating the policy of strict glycemic control before any operative procedures. The diabetic patients should also be routinely screened for the presence of PVD before removal of SV.

Patients with CAD have a high probability of coexisting PVD. Preoperative vascular workup is not mandatory in all patients, but is advised if there is evidence of significant PVD on physical examination. This is particularly important if the vein below the knee is to be harvested. Evaluation of peripheral circulation is done by checking distal arterial pulses and capillary filling. In doubtful cases, it is necessary to do vascular Doppler assessment of ankle pulses and to measure the ankle blood pressure. Scher et al advised against harvesting the $\mathrm{SV}$ if the ankle blood pressure is $50 \mathrm{mmHg}$ or less. ${ }^{37}$ Risk is evaluated by measuring ankle brachial pressure index (ABI). If the $\mathrm{ABI}$ is $<0.7$, further investigation of limb is required. SV harvesting is not advised if the ABI is $<0.5 .^{12} \mathrm{ABIs}$ are not very reliable in very old or diabetic patients. To overcome these limitations, some noninvasive modalities have been developed to assess wound healing potential, such as transcutaneous oximetry (TcPO2) and skin 
perfusion pressure (SPP) testing. TcPO2 takes long time for testing, gives variable results, and has anatomical limitations. $\mathrm{TcPO} 2$ provides metabolic confirmation that oxygen is present in blood and has been regarded as the best predictor of wound healing failure at levels $<30 \mathrm{mmHg}$. SPP testing, on the other hand, appears to be less time consuming, objective, and reliable, and is a measure of distal arterial perfusion and may be representative of both arterial and collateral flow. ${ }^{38}$ Takkin et al showed SPP to be a better predictor of wound healing outcomes than TcPO2 in their study. ${ }^{39}$

If it is mandatory to use ischemic limb for harvesting, then the patient should have angiography of the limbs and, if required, revascularization before cardiac operation.

Preoperative ultrasonic assessment of venous system provides an easy and foolproof way to find the SV, thereby resulting in a direct vertical incision over the vein, less tissue dissection, and good healing of the wound. The preoperative mapping procedure is, therefore, recommended for open SV harvesting and may provide beneficial information regarding size, and it branches, and may prevent unnecessary harvesting of nonusable vein. It may help in changing the decision regarding the vein harvest site and thus reducing the incision length and operative time. It can also be used in endoscopic harvesting to accurately mark the site for incision.

Patients with low preoperative hemoglobin should have their anemia corrected. Postoperative dilutional anemia does not increase the SV harvest wound site complications.

Patient is advised to stop smoking both for good wound outcome as well as for long-term graft patency.

Use of IABP can lead to ischemia of the limb which results in wound healing problems. Most the ischemic problems can be avoided by careful vascular examination prior to balloon insertion and placement of IABP in the other leg where the conduit is not harvested. Regular checking of the pulse by Doppler is a must for early detection of vascular compromise. If there is any evidence of ischemia, removal of the balloon (if hemodynamics of the patient permits) or local embolectomy (if there is thrombus) may suffice. If the patient requires continuous IABP support, use of other leg or femorofemoral arterial bypass is advised for limb survival and wound healing. ${ }^{40,41}$ In recent times, newer heart assist devices such as extra corporeal membrane oxygenation and Impella devices are being used more. These are more helpful, particularly in those cases where peripheral arterial access is not available because of PVD.

The patient's own skin is the most common source of contamination of the wound. Microorganisms can infect the operative field between the skin incision and wound closure.
Therefore, thorough scrubbing of the surgical field is very important. The goal of preoperative skin preparation is to reduce the incidence of surgical site infection (SSI) in a safe, user-friendly, and cost-effective manner. The most common skin preparation agents that are used now include products containing iodophors or chlorhexidine gluconate $(\mathrm{CHG})$. In a multicenter study, alcoholic $\mathrm{CHG}(2 \% \mathrm{CHG} / 70 \%$ isopropyl alcohol) has been shown to be superior to aqueous $10 \%$ povidone-iodine in a prospective randomized clinical trial of clean surgery. ${ }^{42} \mathrm{~A}$ single randomized trial comparing $0.5 \%$ and $2 \%$ CHG (both with $70 \%$ isopropyl alcohol) during vein harvesting showed a nonsignificant trend of greater reduction in the total number of bacteria present on the skin 2 minutes after skin preparation with the stronger solution of CHG. Surgical dressings removed at 24 hours showed a significantly lower number of microorganisms with $2 \% \mathrm{CHG}$ than those in the $0.5 \% \mathrm{CHG}$ cohort. Fewer patients in the $2 \%$ CHG group developed a superficial SSI after discharge at 30 days, compared with those in the $0.5 \%$ group. ${ }^{43}$

At present, the recommendation is removal of hair right before the surgical incision, as shaving of skin with blade much before the incision may cause cuts and abrasion which are colonized by bacteria and increase the chances of postoperative infection. Staphylococcus aureus is associated with most of the superficial infections, whereas Pseudomonas aeruginosa is predominant in deep-seated infection. ${ }^{44} \mathrm{Cur}-$ rent evidence does not support the routine use of mupirocin in surgical prophylaxis. ${ }^{45}$

Despite the implementation of preventive measures such as preoperative antibiotic prophylaxis and antiseptic skin use, SSI rates remain high in cardiac surgery. The use of adhesive drapes helps to immobilize the skin-resident bacterial flora that persists after the application of antimicrobial skin preparations. Bejko et al compared Steri-Drape Cardiovascular Sheet with Ioban ${ }^{\circledR} 2$ versus Hartmann International FolioDrape Cardiovascular set I and found that application of an iodine drape on the skin assured a significantly lower incidence of SSI complications. The use of iodine-impregnated drape, despite being costly, proved to be cost saving. This was due to reduction in the costs related to the treatment of complications, such as use of vacuum-assisted closure (VAC) therapy, hospitalization days, sternal wound revision, antibiotic therapy, and use of antiseptics. ${ }^{46}$

Following the basic surgical principles and proper vein harvest site selection are the most important factors for preventing leg wound infection, more so in patients with compromised lower extremity circulation. It is important to correctly track the course of SV. This will allow minimal 
dissection of tissues and prevention of flaps. It is imperative to have proper control of bleeding, where there is big cavity with lots of fat, particularly in the thigh. Use of drains is recommended to prevent hematoma or seroma formation which can lead to infection. Try to eliminate any dead space formation by closing in multiple layers to prevent collection. Use of minimum cautery on the skin edges, excessive tension on the skin sutures or the staples are to be avoided to prevent ischemic skin necrosis. One should avoid damaging any visible lymphatic channel to prevent lymphocele formation.

Identify the greater saphenous nerve, as it passes close to the GSV. Damage to this nerve can result in paresthesia discomfort to the patient.

After $\mathrm{CABG}$, the leg with vein harvest have increased tendency to develop edema and local complications due to the capillary leak following cardiopulmonary bypass, impaired venous drainage, and extensive lymphatic and soft tissue damage. The fluid accumulates in the interstitial space leading to poor tissue oxygenation and, thus, poor wound healing. Use of graduated compression therapy helps in improvement of the venous and lymphatic drainage in the lower limbs and, thus, can reduce edema and improve microcirculation in the periphery. Reduced edema helps in reducing the wound tension, resulting in improved tissue approximation. AlizadehGhavidel et al found in their study that regular application of thromboembolic deterrent stocking had no effect in prevention of postoperative edema after 1 and 2 weeks, but had significant effect after 4 weeks. Wound complications at the harvest site were much lower in patients without peripheral edema 4 weeks after $\mathrm{CABG}$; thus, thromboembolic deterrent stockings may have beneficial effect. ${ }^{47}$

Different wound closure techniques have been tried to avoid leg wound infection, such as traditional double layer closure, single layer closure, and use of clips. Siddiqi et al ${ }^{48}$ and Zafar et $\mathrm{al}^{49}$ compared single layer versus multiple layer closure techniques and they concluded that single layer closure was superior to the traditional method of closure, *as it showed overall improvement in wound outcomes and less pain.

Conventional open techniques of vein harvesting, despite being meticulous, can result in wound complications. Chukwuemeka and John advised to start the leg incision $5 \mathrm{~cm}$ above the medial malleolus, thus avoiding the more distal area. ${ }^{50}$ Saphenectomy that includes leaving the bridges of skin in between has also been used. Surgical instruments have been devised to facilitate vein harvesting with small incisions. Mini incisions prevent the formation of large skin flaps and cause less injury to lymphatic vessels, thus allowing early recovery. ${ }^{51}$

Now newer techniques utilizing minimally invasive endoscopic harvesting are in vogue and are being used in many centers. ${ }^{35,52-54}$ Minimally invasive techniques using endoscopic and nonendoscopic instruments to reduce surgical incisions and improve the visibility of the SV have been in use since $1996 .{ }^{55}$ There is a reduction in trauma to tissues, reduction in injuries to the cutaneous vessels, and a reduction in postoperative infections. Pagni et al demonstrated a $60 \%$ reduction in the risk of infection in patients undergoing saphenectomy using the video-assisted technique. ${ }^{56}$ These techniques have been widely accepted by both surgeons and patients worldwide. Endoscopic vein harvesting allows to harvest complete length of GSV with excellent visualization, through minimal incision, and gives good postoperative cosmetic results and causes less discomfort. Despite the above advantages, there are concerns regarding the detrimental effect on vein endothelium because of stretching and pulling, and promoting thrombosis, thus leading to early graft closure..$^{57,58}$ Nevertheless, endo vein harvest is associated with less readmission, antibiotic use, wound care, and need for surgical intervention, and should be promoted over the open vein harvesting technique.

\section{Management}

SSI is an acute wound infection developed at the surgical site within 30 days following surgery. The definition of infection which is used worldwide and is adopted by the Centers for Disease Control was given by Horan et al. ${ }^{59}$ According to the definition of the Centers for Disease Control, SSIs are divided into three groups - superficial, deep incisional SSIs, and organ-space SSIs - depending on the site and the extent of infection. Having an objective, accurate, reliable, sensitive, and easily reproducible scoring system to assess the signs and symptoms of SSI can allow prompt evaluation as well as helps in its management. Various scoring systems are used to assess the extent of wound infection. The ASEPSIS system is the only scoring system meant to assess the wounds resulting from cardiothoracic surgery. ${ }^{60}$ ASEPSIS is the acronym which stands for additional treatment, presence of serous discharge, erythema, purulent exudate, and separation of the deep tissues, isolation of bacteria, and duration of inpatient stay (Table 2). It makes assessment of wound sepsis more objective and reproducible by allotting points both for the appearance of the wound in the first week and for the clinical consequences of infection. 
Table 2 The ASEPSIS wound score

Each hospital should have its own wound management guidelines according to the availability of local resources. Tissue viability is an important member to formulate and implement these guidelines. The guidelines should include the introduction of a semi-occlusive postoperative surgical wound dressing as recommended by the National Institute of Health and Clinical Excellence Surgical Site Infection Guidelines. They recommend leaving wounds untouched on the second day, cleaning the wounds only if there is any exudate present, keeping the dressings in place for 7 days, and removing the dressings and exposing the wound on the day of discharge.

If despite all precautions, the patient develops GSVH site complications, immediate attention is to be paid to deal with the problem (Table 3). Pain, redness, heat, discharge,

Table 3 Saphenous vein harvest site wound complications

I. Dermatitis
2. Cellulitis
3. Abscess
4. Hematoma
5. Lymphocele
6. Greater saphenous nerve neuropathy
7. Nonhealing ulcer
8. Gangrene

3. Abscess

4. Hematoma

6. Greater saphenous nerve neuropathy

8. Gangrene

\begin{tabular}{|c|c|c|c|c|c|c|}
\hline \multirow[t]{2}{*}{ Wound characteristic } & \multicolumn{6}{|c|}{ Proportion of wound affected (\%) } \\
\hline & 0 & $<20$ & $20-39$ & $40-59$ & $60-79$ & $>80$ \\
\hline Serous exudate & 0 & I & 2 & 3 & 4 & 5 \\
\hline Erythema & 0 & $\mathrm{I}$ & 2 & 3 & 4 & 5 \\
\hline Purulent exudates & 0 & 2 & 4 & 6 & 8 & 10 \\
\hline Separation of deep tissues & 0 & 2 & 4 & 6 & 8 & 10 \\
\hline Criteria & \multicolumn{6}{|c|}{ Points } \\
\hline \multicolumn{7}{|l|}{ Additional treatment } \\
\hline Antibiotics & \multicolumn{6}{|c|}{10} \\
\hline $\begin{array}{l}\text { Drainage of pus under local } \\
\text { anesthesia }\end{array}$ & \multicolumn{6}{|l|}{5} \\
\hline $\begin{array}{l}\text { Debridement of wound } \\
\text { (general anesthesia) }\end{array}$ & \multicolumn{6}{|c|}{10} \\
\hline Serous discharge & \multicolumn{6}{|c|}{ Daily 0-5 } \\
\hline Erythema & \multicolumn{6}{|c|}{ Daily 0-5 } \\
\hline Purulent exudates & \multicolumn{6}{|c|}{ Daily 0-I0 } \\
\hline Separation of deep tissues & \multicolumn{6}{|c|}{ Daily 0-10 } \\
\hline Isolation of bacteria & \multicolumn{6}{|c|}{10} \\
\hline $\begin{array}{l}\text { Stay as inpatient prolonged } \\
\text { over } 14 \text { days }\end{array}$ & \multicolumn{6}{|l|}{5} \\
\hline \multicolumn{7}{|l|}{ Category of infection } \\
\hline \multicolumn{7}{|l|}{ Total score } \\
\hline $0-10$ & \multicolumn{6}{|c|}{ Satisfactory healing } \\
\hline $11-20$ & \multicolumn{6}{|c|}{ Disturbance of healing } \\
\hline $21-30$ & \multicolumn{6}{|c|}{ Minor wound infection } \\
\hline $31-40$ & \multicolumn{6}{|c|}{ Moderate wound infection } \\
\hline$>40$ & \multicolumn{6}{|c|}{ Severe wound infection } \\
\hline
\end{tabular}
for the first 48 hours postoperatively, reviewing all dressings

hardening of incisions, and fever are the most frequent signs of infection and usually start on the third or fourth day of surgery. The problem can range from minor cutaneous manifestation such as cellulitis, pruritus, eczematous reaction, xerosis, hyperpigmentation, and hypertrophic scar to major problem such as skin wound necrosis, abscess formation, hematoma, lymphocele, nonhealing ulcer, and venous gangrene, which may require major operative intervention that will vary depending on the extent and etiology of the problem (Table 4).

In the wounds with first intention healing, nonoperative techniques will suffice with simple moist dressing. If there is cellulitis and inflammation, limb elevation and use of broad-spectrum antibiotics according to hospital polices are advised. Treatment of wounds with the presence of discharge and inflammation involves debridement of dead tissues and removal of surgical sutures, hematomas, and clots (Table 5). In open wounds, povidone-iodine and chlorhexidine solutions should not be used as they may affect the healing process and can also reduce the tensile strength of the tissues.

If the wounds are large, healing by secondary intention will take a long time, delaying the patient's recovery. In the past, the treatment of choice was delayed wound closure with plastic surgical procedures such as split-thickness skin grafting, rotational flaps, or free tissue transfer.

Table 4 Operative procedures for saphenous vein harvest wound complications

I. Prompt drainage of hematomas, lymphoceles, and abscesses

2. Debridement

3. Delayed closure of wound after VAC dressing

4. Fasciotomy

5. Thromboembolectomy with or without bypass

6. Delayed wound closure with skin graft or rotational flap

7. Free tissue transfer

8. Amputation

Abbreviation: VAC, vacuum-assisted closure.

Table 5 Types and treatment of wound

\begin{tabular}{ll}
\hline Type of wound & Treatment \\
\hline Dry and first intention & $\begin{array}{l}0.9 \text { Normal saline, cover with sterile } \\
\text { gauze. Change at least once a day or }\end{array}$ \\
when dressing is soaked \\
Open and with little exudation & $\begin{array}{l}\text { Saline solution jets, manual } \\
\text { debridement, cover with gauze } \\
\text { soaked in SS or medium chain } \\
\text { triglycerides or hydrocolloid. } \\
\text { Change daily or when soaked }\end{array}$ \\
Open and with abundant exudation & $\begin{array}{l}\text { Saline solution jets, manual } \\
\text { debridement, cover with gauze } \\
\text { soaked in calcium alginate. Change } \\
\text { daily or when soaked, VAC dressing }\end{array}$ \\
\hline
\end{tabular}

Abbreviations: SS, saline solution; VAC, vacuum-assisted closure. 
With the advent of newer techniques of wound management, less number of patients requires these types of aggressive procedures.

The nonoperative treatment options available for the management of large wounds are mentioned below.

\section{Long chain triglycerides - DERSANI}

It was introduced by Declair in $1994 .{ }^{11}$ It promotes chemotaxis and angiogenesis, thus accelerating tissue granulation. In this, the wound is first washed with saline and then covered with gauze soaked in long chain triglycerides. Dressing is done daily or as required.

\section{Hydrocolloid dressing}

It has an inner and outer layer. The inner layer absorbs the soakage and maintains moist environment. It is made of gelatin and pectin and stimulates angiogenesis and autolytic debridement. The outer layer is formed of polyurethane foam, which forms a thermal barrier against gases and liquids. It is preferable to use them in clean wounds without and dead tissues. Dressing is changed within a week or whenever the gel overflows.

\section{Calcium alginate dressing}

It is derived from brown algae. It is most useful for wounds with copious discharge, with or without infection, and for wounds with deep cavities. It is very absorptive and helps in autolytic process. Dressing is required every 3-4 days.

\section{Negative pressure VAC}

The idea of exposing a wound to negative pressure for an extended period to promote debridement and healing was first described by Fleischmann et al in $1993 .{ }^{62}$ The application of controlled levels of subatmospheric pressure has been shown to help early debridement and promote healing in a variety of wounds. The optimum level of negative pressure appears to be around $125 \mathrm{mmHg}$ below the ambient pressure, and there are studies which show that this is most effective if applied in a cyclical fashion of 5 minutes on and 2 minutes off. It is hypothesized that the negative pressure assists in the removal of interstitial fluid, reducing localized edema and increasing the blood flow. This, in turn, decreases tissue bacterial counts and also helps draw the wound edges together. In addition, mechanical deformation of cells is thought to result in protein and matrix molecule synthesis, which increases the rate of cell proliferation and actively promotes granulation, thus expediting wound closure. ${ }^{63}$ This is suitable for large wounds which will otherwise take long time to heal by secondary intention. Once the wound is debrided and is relatively clean, VAC device (Kinetic concepts Inc., San Antonia, TX, USA) can be applied. With this system, patient can remain ambulatory. Wound healing rates with this technique are excellent (Figures 1-3). In our practice, we are using the VAC device extensively and have found the results very encouraging.

\section{Tissue-engineered human skin equivalent}

The skin equivalent (Apligraf ${ }^{\circledR}$; Novartis Pharmaceuticals Corporation, East Hanover, NJ, USA) comprises a dermal equivalent, and is reconstituted with collagen and dermal fibroblasts that are biosynthetically active and have a differentiated epidermis that arises from cultured keratinocytes put onto the surface of the dermal equivalent. This is another nonsurgical option for treatment of chronic wounds that gives good results. ${ }^{64}$ This can be done as an outpatient procedure. Living skin equivalent increases the healing rate and promotes healing. Patients with SV harvest wounds with compromised circulation can have good healing without revascularization

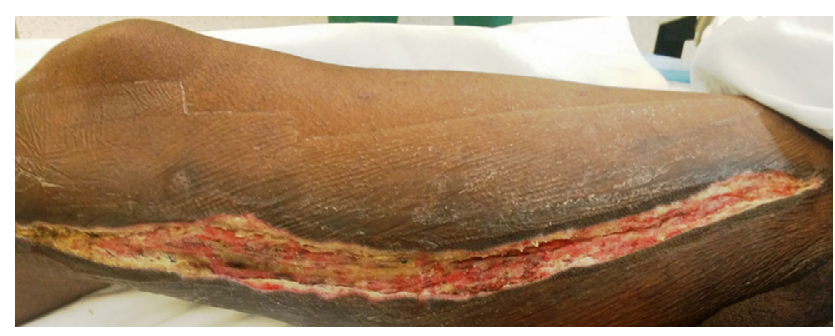

Figure I Wound before application of VAC dressing. Abbreviation: VAC, vacuum-assisted closure.

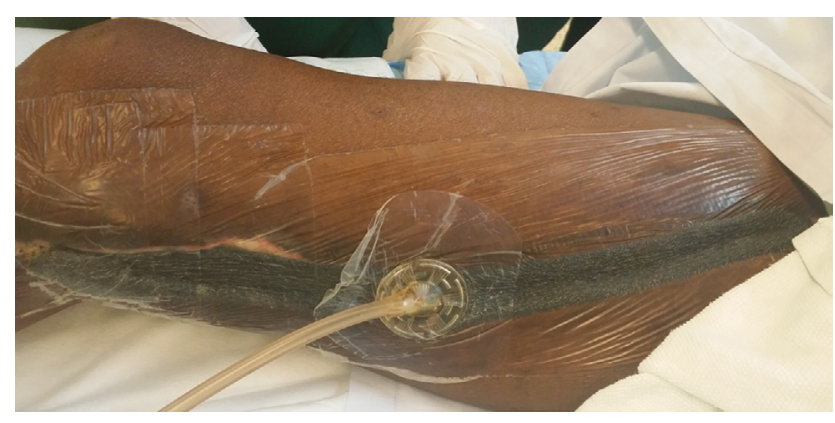

Figure 2 Application of VAC dressing on the wound. Abbreviation: VAC, vacuum-assisted closure.

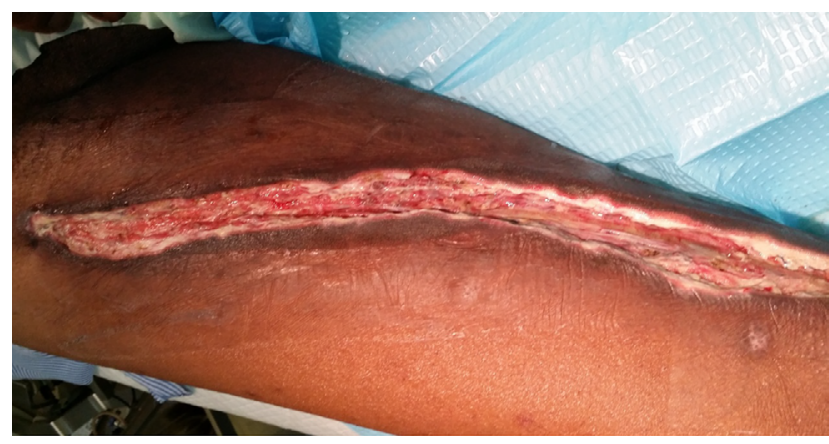

Figure 3 Wound after VAC dressing.

Abbreviation: VAC, vacuum-assisted closure. 


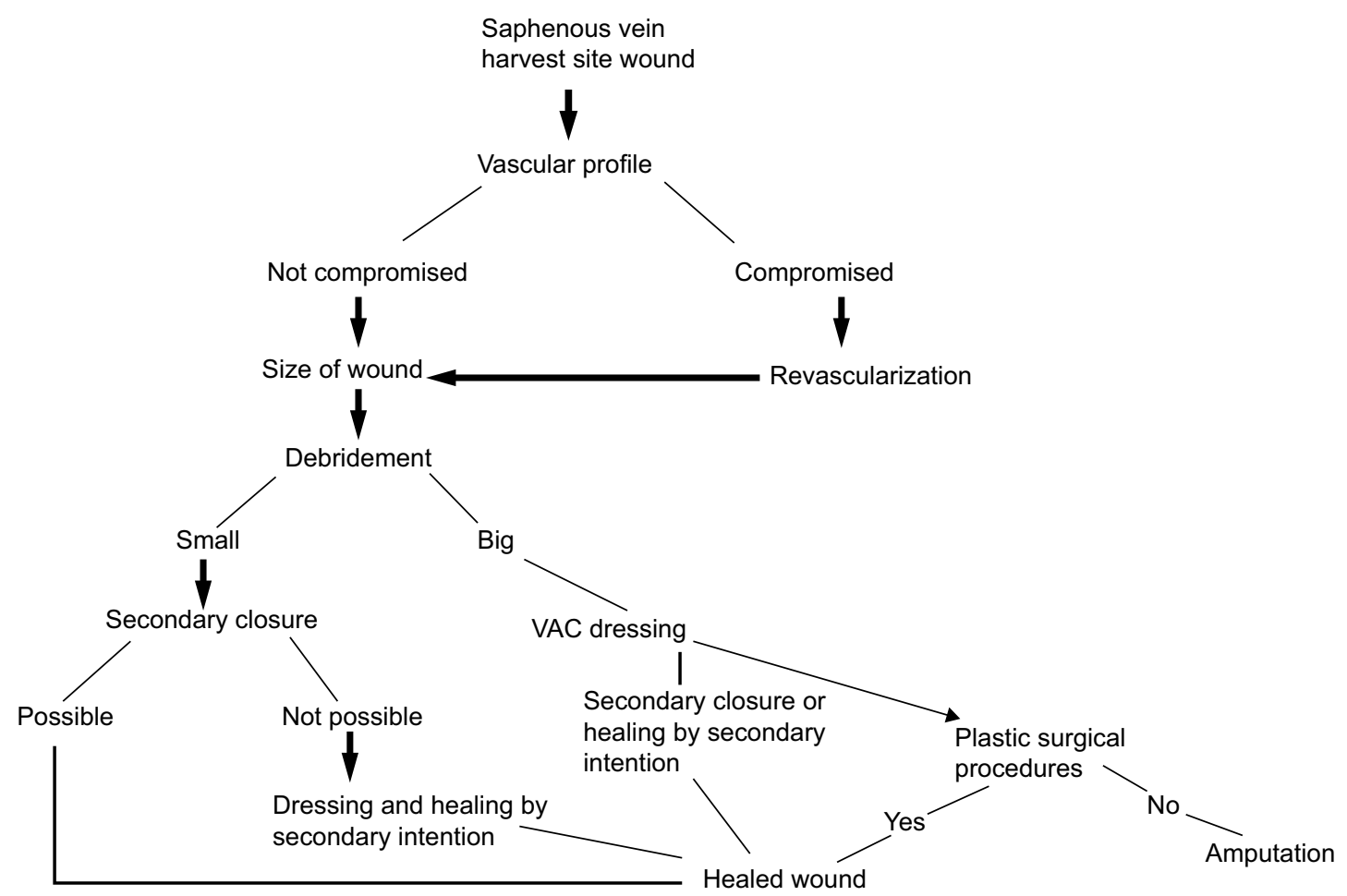

Figure 4 Algorithm for the management of saphenous vein harvest site wound.

Abbreviation: VAC, vacuum-assisted closure.

when treated by this method. Treadwell has shown that the cosmetic result of tissue-engineered skin is better than the use of a split-thickness graft. ${ }^{65}$

\section{Bilayered cellular matrix}

Bilayered cellular matrix $\left(\mathrm{OrCel}^{\mathrm{TM}}\right.$; Ortec International, New York, NY, USA) is a porous collagen sponge containing cocultured allogeneic keratinocytes and fibroblasts harvested from human neonatal foreskin. ${ }^{66}$ It has been used in patients with chronic venous ulcers and has shown promising results.

In patients in whom the wound is big and the edges of the wound cannot be approximated and cannot be managed by the above-mentioned conservative procedures, plastic surgical procedures should be used. If ischemia is the cause of wound problem, then it must be managed by restoration of blood supply. In extreme cases where circulation cannot be restored and limbs appear unsalvageable, amputation is the only option.

Figure 4 shows the algorithm for the management of SV harvest site wound.

\section{Conclusion}

The causes of major leg wound complications after GSV harvest for $\mathrm{CABG}$ procedures are multifactorial and complex. Major GSVHSI after CABG is not very common; but if it occurs, it is a cause of morbidity and delayed recovery for the patients. Various studies suggest female sex, DM, postoperative use of IABP, obesity, preexisting PVD, and hyperlipidemia as strong independent risk factors of major leg wound complications. The management of these complications depends on the severity of the problem and ranges from simple debridement and regular dressing to more advanced plastic surgery procedures using microvascular techniques. Potential serious complications can be avoided by thorough preoperative assessment of patients at risk, obtaining preoperative vascular evaluations especially in patients with compromised lower extremity circulation, selecting proper vein harvest sites and employing meticulous surgical techniques, early recognition and treatment of complications, and having low threshold for aggressive approach for established complications. Judicious use of newer treatment modalities in a timely fashion may be beneficial in the nonoperative treatment of these patients.

\section{Acknowledgment}

The patients provided written informed consent for publication of the images.

\section{Disclosure}

The authors report no conflicts of interest in this work.

\section{References}

1. Athanasiou T, Aziz O, Skapinakis P, et al. Leg wound infection after coronary artery bypass grafting: a meta-analysis comparing minimally invasive versus conventional vein harvesting. Ann Thorac Surg. 2003;76(6): 2141-2146. 
2. Perrault LP, Jeanmart H, Bilodeau L, et al. Early quantitative coronary angiography of saphenous vein grafts for coronary artery bypass grafting harvested by means of open versus endoscopic saphenectomy: a prospective randomized trial. J Thorac Cardiovasc Surg. 2004;127(5): 1402-1407.

3. DeLaria GA, Hunter JA, Goldin MD, Serry C, Javid H, Najafi H. Leg wound complications associated with corona revascularization. JThorac Cardiovasc Surg. 1981;81(3):403-407.

4. Mullen JC, Bentley MJ, Mong K, et al. Reduction of leg wound infections following coronary arterybypass surgery. Can J Cardiol. 1999; 15(1):65-68

5. Goldsborough MA, Miller MH, Gibson J, Creighton-Kelly S, Custer CA, Wallop JM, Greene PS. Prevalence of leg wound complications after coronary artery bypass graft determination of risk factors. Am J Crit Care. 1999;8(3):149-153.

6. Folliguet TA, Le Bret E, Moneta A, Musumeci S, Laborde F. Endoscopic vein harvesting versus open technique: a prospective study. Eur J Cardiothorac Surg. 1998;13(6):662-666.

7. Roy MC. Surgical- site infections after coronary artery bypass graft surgery: discriminating site specific risk factors to improve prevention efforts. Infect Control Hosp Epidemiol. 1998;19(4):229-233.

8. Spelman DW, Russo P, Harrington G, Davis BB, Rabinov M, Smith JA, Esmore D. Risk factors for surgical wound infection and bacteraemia following coronary artery bypass surgery. Aust $N$ Z J Surg. 2000 70(1):47-51.

9. L'Ecuyer PB, Murphy D, Little JR, Fraser VJ. The epidemiology of chest and leg wound infections following cardiothoracic surgery. Clin Infect Dis. 1996;22(3):424-429.

10. Olsen MA, Sundt TM, Lawton JS, Damiano RJ, Hopkins-Broyles D, Luck-Buckley P, Fraser VJ. Risk factors for leg harvest surgical site infections after coronary artery bypass graft surgery. J Thorac Cardiovasc Surg. 2003;126(4):992-999.

11. Thomas TA, Taylor SM, Crane MM, Cornett WR, Langan EM 3rd, Snyder BA, Cull DL. An analysis of limb-threatening lower extremity wound complication after 1090 consecutive coronary artery bypass procedures. Vasc Med. 1999;4(2):83-88.

12. Paletta CE, Huang DB, Fiore AC, Swartz MT, Rilloraza FL, Gardner JE. Major leg wound complications after saphenous vein harvest for coronary revascularization. Ann Thorac Surg. 2000;70(2):492-497.

13. Utley JR, Thomason ME, Wallace DJ, et al. Preoperative correlates of impaired wound healing after saphenous vein excision. J Thorac Cardiovasc Surg. 1989;98(1):147-149.

14. Swenne CL, Lindholm, Borowiec J, Carlsson M. Surgical site infections within 60 days of coronary artery bypass graft surgery. J Hosp Infect. 2004;57(1):14-24.

15. Engelman DT, Adams DH, Byrne JG, et al. Impact of body mass index and albumin on morbidity and mortality after cardiac surgery. JThorac Cardiovasc Surg. 1999;118(5):866-873.

16. Kuduvalli M, Grayson AD, Oo AY, Fabri BM, Rashid A. Risk of morbidity and in hospital mortality in obese patients undergoing coronary artery bypass surgery. Eur J Cardiothorac Surg. 2002;22(5):787-793.

17. Brandt M, Hardr K, Walluscheck KP, Fraund S, Boning A, Creamer J. Coronary artery bypass in diabetic patients. J Card Surg. 2004;19(1): 36-40.

18. Black EA, Cambell K, Channon KM, Ratnatunga C, Pillai R. Minimally invasive vein harvesting significantaly reduces pain and wound morbidity. Eur J Cardiothorac Surg. 2002;22(3):381-386.

19. Carrizo CJ, Livesay JJ, Luy L. Endoscopic harvesting of the greater saphenous vein. Tex Heart Inst J. 1999;26(2):120-123.

20. Kiaii B, Moon BC, Massel D, et al. A prospective randomized trial of endoscopic versus conventional harvesting of the saphenous vein in coronary artery bypass surgery. J Thorac Cardiovasc Surg. 2002;123(2):204-212.

21. Bitondo JM, Daggett WM, Torchiana DF, et al. Endoscopic versus open saphenous vein harvest: a comparison of postoperative wound complications. Ann Thorac Surg. 2002;73(2):523-528.

22. Kayacioglu I, Camur G, Gunay R, et al. The risk factors affecting the complications of saphenous vein graft harvesting in aortocoronary bypass surgery. Tohoku J Exp Med. 2007;211(4):331-337.
23. Hasselquist MB, Goldberg N, Schroeter A, Spelsberg TC. Isolation and characterization of the estrogen receptor in human skin. J Clin Endocrinol Metab. 1980;50(1):76-82.

24. Shanker G, Sorci-Thomas M, Adams MR. Estrogen modulates the inducible expression of platelet-derived growth factor mRNA by monocyte/macrophages. Life Sci. 1995;56(7):499-507.

25. Morain WD, Colen LB. Wound healing in diabetes mellitus. Clin Plast Surg. 1990;17(3):493-501.

26. Bakhai A, Collinson J, Flather MD, et al. Diabetic patients with acute coronary syndromes in the UK: high risk and under treated. Results from the prospective registry of acute ischaemic syndromes in the UK (PRAIS-UK. Int J Cardiol. 2005;100(1):79-84.

27. Garland R, Frizelleb FA, Dobbsb RA, Singh H. A retrospective audit of long term lower limb complications following leg vein harvesting for coronary artery bypass grafting. Eur J Thorac Cardiovasc Surg. 2003;23(6):950-955.

28. $\mathrm{Ku} \mathrm{CH}, \mathrm{Ku}$ SL, Yin JC, Lee AJ. Risk factors for sternal and leg surgical site infections after cardiac surgery in Taiwan. Am J Epidemiol. 2005; 161(7):661-671.

29. Harvath KD, Gray D, Hill J, Swanstrom LL. Operative outcomes of minimally invasive saphenous vein harvest. Am J Surg. 1998;175(5): 391-395.

30. Zia S, Ndoye A, Lee TX, Webber RJ, Grando SA. Receptor-mediated inhibition of keratinocyte migration by nicotine involves modulations of calcium influx and intracellular concentration. J Pharmacol Exp Ther. 2000;293(3):973-981.

31. Tiwari A, Haq AI, Myint F, Hamilton G. Acute compartment syndromes. Br J Surg. 2002;89:397-412.

32. Mumoli N, Invernizzi C, Luschi R, Carmignani G, Camaiti A, Cei M. Phlegmasia cerulea dolens. Circulation. 2012;125(8):1056-1057.

33. Mackenzie DJ, Wagner WH, Kulber DA, et al. Vascular complications of the intra-aortic balloon pump. Am J Surg. 1992;164(5):517-521.

34. Baddour LM, Bisno AL. Recurrent cellulitis after saphenous venectomy for coronary bypass surgery. Ann Intern Med. 1982;97(4):493-496.

35. Allen KB, Griffith GL, Heimansohn DA, et al. Endoscopic versus traditional saphenous vein harvesting: a prospective, randomized trial. Ann Thorac Surg. 1998;66(1):26-31.

36. Angelini GD, Butchart EG, Armistead SH, Breckenridge IM. Comparative study of leg wound closure in coronary artery bypass graft operations. Thorax. 1984;39(12):942-945.

37. Scher LA, Samson RH, Ketosugbo A, Gupta SK, Ascer E, Veith FJ. Prevention and management of ischemic complications of vein harvest incisions in cardiac surgery: case reports. Angiology. 1986;37(2):119-123.

38. Frykberg RG, Zgonis T, Armstrong DG, et al. Diabetic foot disorders A clinical practice guideline. J Foot Ankle Surg. 2006;45(5 Suppl): S1-S66.

39. Takkin Lo, Sample R, Moore P, Gold P. Prediction of wound healing outcome using skin perfusion pressure and transcutaneous oximetry: a single-center experience in 100 patients. Wounds. 2009;21(11):310-316.

40. Barnett MG, Swartz MT, Peterson GJ, et al. Vascular complications from intraaortic balloons: risk analysis. JVasc Surg. 1994;19(1):81-87.

41. Friedell ML, Alpert J, Parsonnet V, Brief DK, Brener BJ, Goldenkranz RJ, Nozick J. Femorofemoral grafts for lower limb ischemia caused by intra-aortic balloon pump. J Vasc Surg. 1987;5(1):180-186.

42. Darouiche RO, Wall MJ Jr, Itani KM, et al. Chlorhexidine-alcohol versus povidone-iodine for surgical-site antisepsis. NEngl J Med. 2010; 362(1):18-26.

43. Casey AL, Itrakjy AS, Harbun C, et al. Prospective, randomised clinical trial to compare the efficacy of two $70 \%$ isopropyl alcohol (IPA) solutions containing either $0.5 \%(\mathrm{v} / \mathrm{v})$ or $2 \%(\mathrm{v} / \mathrm{v})$ chlorhexidine gluconate $(\mathrm{CHG})$ for skin antisepsis during coronary artery bypass grafting (CABG). Poster presented at: European Congress of Clinical Microbiology and Infection Diseases (ECCMID); Barcelona, Spain; April 2008.

44. Sharma M, Berriel-Cass D, Baran J. Sternal surgical-site infections following coronary artery bypass graft: prevalence, microbiology and complications during a 42-month period. Infect Control Hosp Epidemiol. 2004;25(6):468-471. 
45. Konvalinka A, Errett L, Fong IW. Impact of treating Staphylococcus aureus nasal carriers on wound infections in cardiac surgery. $J$ Hosp Infect. 2006;64(2):162-168.

46. Bejko J, Tarzia V, Carrozzini M, et al. Comparison of efficacy and cost of iodine impregnated drape vs. standard drape in cardiac surgery: study in 5100 patients. J Cardiovasc Transl Res. 2015;8(7):431-437.

47. Alizadeh-Ghavidel A, Ramezannejad P, Mirmesdagh Y, SadeghpourTabaei A. Prevention of edema after coronary artery bypass graft surgery by compression stockings. Res Cardiovasc Med. 2014;3(2):e17463.

48. Siddiqi MS, Al Sabti H, Mukaddirov M, Sharma AK. Prospective comparative study of single-layer versus double-layer closure of leg wounds after long saphenous vein harvest in coronary artery bypass graft operations. J Thorac Dis. 2011;3(3):171-176.

49. Zafar M, John A, Khan Z, Allen SM, et al. Single layer versus multiple layer closure of leg wounds after long saphenous vein harvest: a prospective randomized trial. Ann Thorac Surg. 2005;80(6):2162-2165.

50. Chukwuemeka A, John L. Modified incision for long saphenous vein harvest. Ann Thorac Surg. 1998;66(1):279.

51. Tevaearai HT, Mueller XM, von Segesser LK. Minimally invasive harvest of the saphenous vein for coronary artery bypass grafting. Ann Thorac Surg. 1997;63(6 Suppl):S119-S121.

52. Morris RJ, Butler MT, Samuels LE. Minimally invasive saphenous vein harvesting. Ann Thorac Surg. 1988;66(3):1026-1028.

53. Davis Z, Jacobs HK, Zhang M, Thomas C, Castellanos Y. Endoscopic vein harvest for coronary artery bypass grafting: technique and outcomes. J Thorac Cardiovasc Surg. 1998;116(2):228-235.

54. Folliguet TA, Le Bert E, Moneta A, Musumeci S, Laborde M. Endoscopic saphenous vein harvesting versus 'open' technique. A prospective study. Eur J Cardiothorac Surg. 1998;13:662-666.

55. Lumsden AB, Eaves FF III, Ofenloch JC, Jordan WD. Subcutaneous video assisted saphenous vein harvest: report of the first 30 cases. Cardiovasc Surg. 1996;4(6):771-776.
56. Pagni S, Ulfe EA, Montgomery WD, VanHimbergen DJ, Fisher DJ, Gray LA Jr, Spence PA. Clinical experience with the video-assisted saphenectomy procedure for coronary bypass operations. Ann Thorac Surg. 1998;66(5):1626-1631.

57. Rousou LJ, Taylor KB, Lu XG, Healey N, Crittenden MD, Khuri SF, Thatte HS, Thatte HS. Saphenous vein conduits harvested by endoscopic technique exhibit structural and functional damage. Ann Thorac Surg. 2009;87(1):62-70.

58. Zenati M, Shroyer L, Collins J, et al. Impact of endoscopic versus open saphenous vein harvest technique on late coronary artery bypass grafting patient outcomes in the ROOBY (randomized on/off bypass) trial. J Thorac Cardiovasc Surg. 2011;141(2):338-344.

59. Horan TC, Gaynes RP, Martone WJ. CDC definitions of nosocomial surgical site infections, 1992: a modification of CDC definitions of surgical wound infections. Infect Control Hosp Epidemiol. 1992;13(10):606-608.

60. Wilson APR, Weavill C, Burridge J, Kelsey MC. The use of the wound scoring method 'ASEPSIS' in postoperative wound surveillance. J Hosp Infect. 1990;16(4):297-309.

61. Declair V. Aplicação do triglicerídios de cadeia média (TCM) na prevenção de úlceras de decúbito. Rev Bras Enf. 1994;47(1):27-30. Portuguese.

62. Fleischmann W, Strecker W, Bombelli M, Kinzl L. [Vacuum sealing as treatment of soft tissue damage in open fractures]. Unfallchirurg. 1993;96(9):488-492. German.

63. Eaglstein WH, Iriondo M, Laszlo K. A composite skin substitute (Graftskin) for surgical wounds. Dermatol Surg.1995;21(10):839-843.

64. Mendez-Eastman S. Negative pressure wound therapy. Plastic Surg Nursing. 1998;18(1):27-37.

65. Treadwell T. Management of saphenous vein harvest wound complications following coronary artery bypass grafting. Wounds. 2003;15(3):83-91.

66. Silberklang M. Mechanisms of wound healing: studies with the bilayered cellular matrix, OrCel. [Manufacturer's information] New York City, NY: Ortec International, Inc.; 2002.
Chronic Wound Care Management and Research

\section{Publish your work in this journal}

Chronic Wound Care Management and Research is an international, peer reviewed, open access, online journal publishing original research, reviews, editorials, and commentaries on the causes and management of chronic wounds and the major issues related to chronic wound management. Topics also include chronic wounds as comorbidities to other

\section{Dovepress}

conditions, patient adherence to therapy, and the economic burden of chronic wounds. The manuscript management system is completely online and includes a very quick and fair peer review system, which is all easy to use. Visit http://www.dovepress.com/testimonials.php to read real quotes from published authors. 